Article

\title{
The Bargiolina, a Striking Historical Stone from Monte Bracco (Piedmont, NW Italy) and a Possible Source of Industrial Minerals
}

\author{
Alessandro Cavallo ${ }^{1, *(D)}$ and Giovanna Antonella Dino ${ }^{2}$ \\ 1 Department of Earth and Environmental Sciences-DISAT, University of Milano-Bicocca, Piazza della \\ Scienza, 1-4, 20126 Milano, Italy \\ 2 Department of Earth Sciences, University of Turin, Via Valperga Caluso, 35, 10125 Torino, Italy \\ * Correspondence: alessandro.cavallo@unimib.it; Tel.: +39-338-2343834
}

Received: 22 June 2019; Accepted: 6 August 2019; Published: 8 August 2019

\begin{abstract}
The Bargiolina quartzite from Monte Bracco (western Alps, northern Italy) represents one of the most important historical ornamental stones of the Piedmont region. Known and used since the prehistoric age as substituting material for chert, it was celebrated by Leonardo da Vinci, and exploited at least since the XIII century, peaking in the XX century. It was extensively used in the construction of basilicas and noble palaces by famous architects of Piedmontese Baroque, for internal and external stone cladding. There are four main commercial and chromatic varieties, and the main technical feature is the regular schistosity, to obtain very thin natural split slabs. The different varieties have a homogeneous mineralogical composition and microstructure: A fine and homeoblastic grain size, and a granular-lepidoblastic texture, with regularly spaced schistose domains. The main rock-forming minerals are quartz, phengite, small amounts of K-feldspar and traces of plagioclase and chlorite. The yield rate of quarries is about $20 \%$, and the poor exploitation planning of the past led to only partly exploited quarry benches, with a very poor residual yield. The large amount of quartz-rich quarry waste and the presence of kaolin-rich gneisses suggests the potential for novel applications in the field of industrial minerals.
\end{abstract}

Keywords: heritage stone; quartzite; Bargiolina; quarries; dimension stone; kaolin; industrial minerals

\section{Introduction}

Bargiolina is the term that defines a group of four main varieties of quartzites extracted from Monte Bracco (1306 m a.s.l.), an isolated mountain close to the village of Barge (western Alps, northern Italy), approximately $40 \mathrm{~km}$ from Turin and Cuneo (Figure 1). Known and used since the prehistoric age as substituting material for chert, the Bargiolina has been exploited in slabs at least since the XIII century, peaking in the XX century (up to $300 \mathrm{kt} /$ year), used as internal and external facing because of its excellent technical proprieties [1,2]. The first reliable report on its use date back to 1374, to the statutes granted by Amedeo VI of Savoy to the town of Barge, in which it was ordered to maintain the paths that led from the city to the quarries on Monte Bracco in good condition. The use was increased by another Savoyard, Ludovico (1413-1465): The one who bought the Holy Shroud (Sindone) and forbade the citizens of Barge the roof covers in wood or straw. Leonardo Da Vinci, on 5 January 1511, celebrated the quartzite and described Monte Bracco as "... rich in a stratified which is white as the Carrara marble, is speckled and hard as a porphyry ... " [3]. Between the XVII and XVIII centuries the quarries worked at full speed to meet the needs of great architects of the Piedmontese Baroque such as Guarino Guarini (1624-1683), Filippo Juvarra (1678-1736), Francesco Gallo (1672-1750) and Benedetto Alfieri (1699-1767) in the construction of basilicas and noble palaces (Figure 2): From the 
Guarini towers of the Racconigi Castle (Cuneo) to the salon of the first subalpine parliament in Palazzo Madama (Turin), and from the Stupinigi Castle (in the district of Nichelino in Turin) to the Reggia di Venaria (Venaria Reale, Turin). Filippo Juvarra used the Bargiolina in the flooring of the side wings of the Stupinigi hunting lodge and in the cloister of the Superga Basilica (Turin). In the second half of the XIX century and at the beginning of the XX century, the quartzite was marketed in northern Italy and exported to Russia and South America [1]. Waste materials were milled to be transformed into powder and used as a coating material for the cylinders of cement mills, as a powder for cleaning cannon barrels and even as a component of toothpaste. Nowadays, only two quarries are involved in the occasional exploitation of very small amounts of quartzite. The aim of this paper is to highlight the features of this stone and to characterize its potential in the industrial minerals sector.

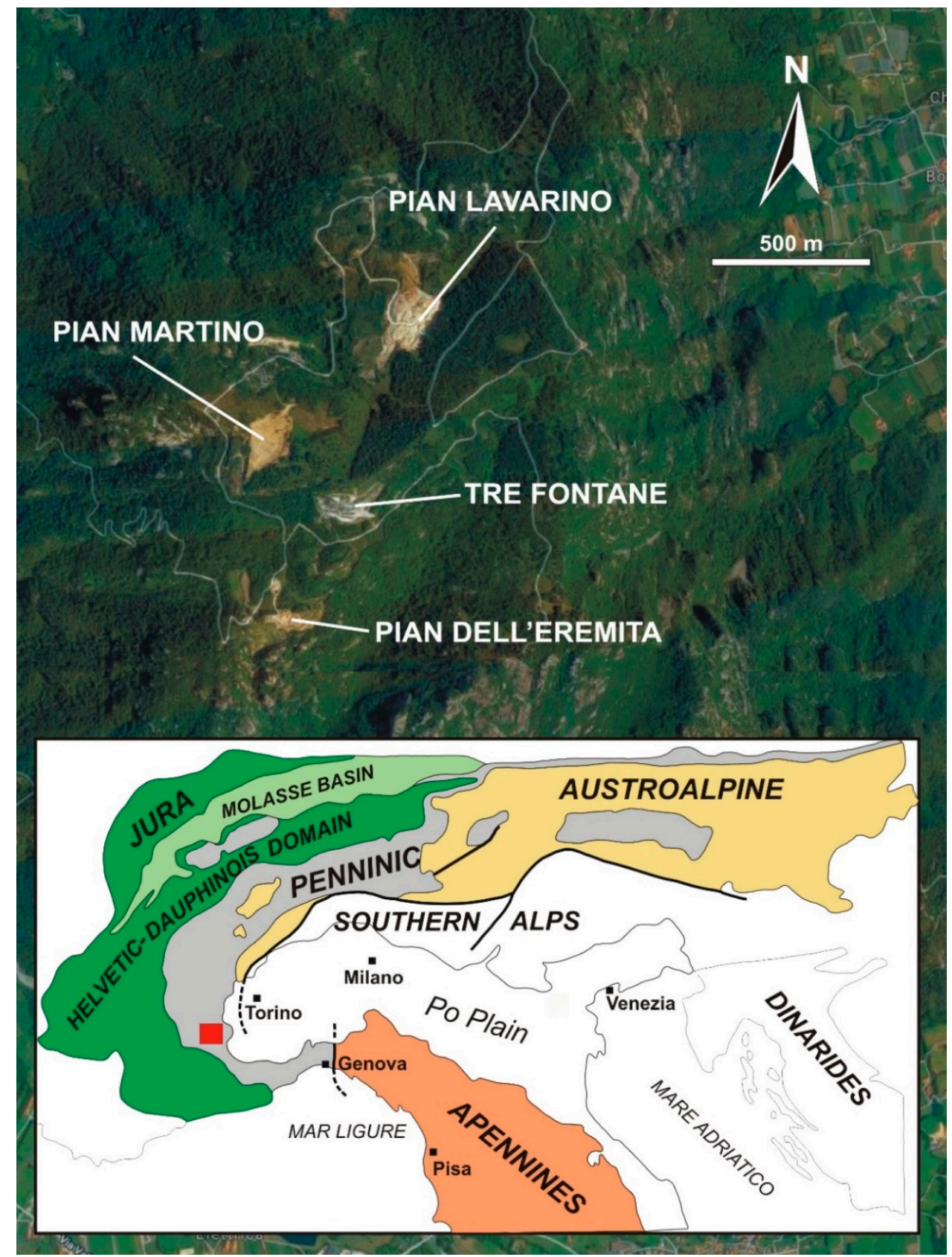

Figure 1. Geological framework of the Alps and aerial view (from Google Earth) of the Monte Bracco main quarry areas. 

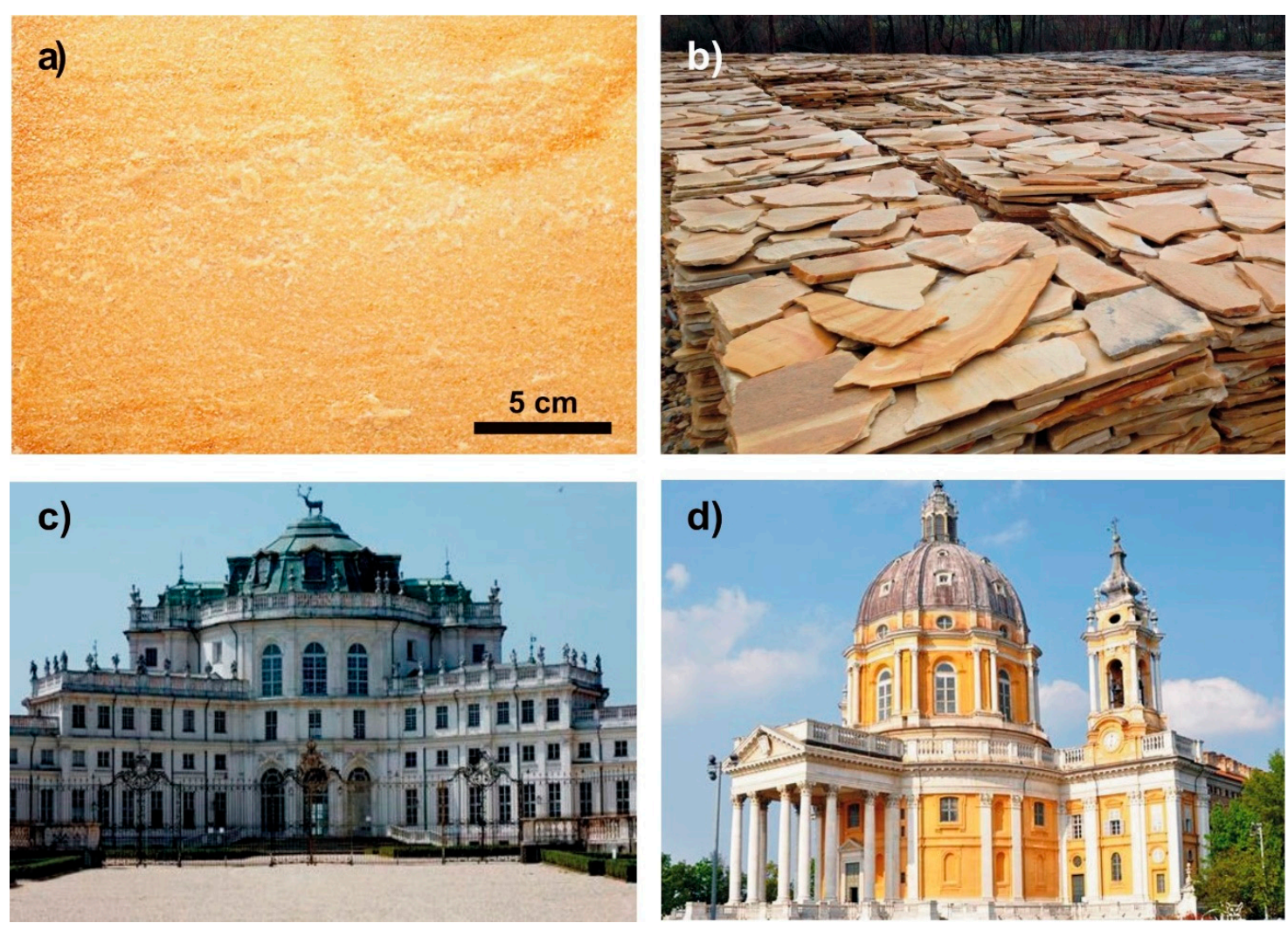

Figure 2. (a) "Golden" quartzite slab; (b) stacked quartzite slabs on the quarry floor; (c) Stupinigi hunting lodge (district of Nichelino in Turin); and (d) Superga basilica (Turin).

\section{Materials and Methods}

A total of 18 representative quartzite samples from the main quarry areas (Barge and Sanfront municipalities), as well as 5 kaolinitic gneisses (the host rock of quartzites) were characterized by polarized light optical microscopy on thin sections, X-ray powder diffraction (XRD) and bulk chemistry (X-ray fluorescence-XRF). The XRD analyses were performed using a PANalytical X'Pert PRO PW3040/60 X-ray diffractometer with Ni-filtered $\mathrm{Cu} \mathrm{K} \alpha$ radiation at $40 \mathrm{kV}$ and $40 \mathrm{~mA}, \frac{1}{2}{ }^{\circ}$ divergence and receiving slits, and step scan of $0.02^{\circ} 2 \theta$, in the $3-80^{\circ} 2 \theta$ range. The limit of detection (LOD) of XRD depends on the mineral phase and is generally comprised between $0.1 \mathrm{wt}$. \% for highly crystalline phases and $2 \mathrm{wt}$. \%. The qualitative XRPD analysis was performed running the X'Pert High-Score ${ }^{\circledR}$ software (Malvern Panalytical Ltd., Almelo, the Netherlands) using the ICSD PDF2 database. A semi-quantitative evaluation of the relative abundance of single minerals was obtained with the internal standard technique (by adding $20 \mathrm{wt}$. \% of NIST SRM 676a $\alpha$-corundum powder) and the reference intensity ratio (RIR) method [4]. Whole-rock geochemistry (major elements) was assessed by energy-dispersive XRF (Panalytical Epsilon 3-XL spectrometer), whereas physical and technical properties were taken from the literature [5,6].

\section{Geological Framework}

The Monte Bracco area is located in the Dora-Maira Massif (DMM), a crystalline massif (Paleozoic basement and a thin Mesozoic cover) belonging to the inner part of the Penninic Domain, together with the Monte Rosa and the Gran Paradiso Massifs, extending more than $1000 \mathrm{~km}^{2}$ in the central sector of the Cottian Alps (western Alps) [7,8]. The southern part of DMM is composed of four main tectonometamorphic units, from the lower to the upper structural levels: The Pinerolo, San Chiaffredo, Brossasco-Isasca and Rocca Solei units [9]. In its northern sector, the DMM comprises two main units that, during Alpine orogeny, were metamorphosed under different pressure-temperature $(\mathrm{P}-\mathrm{T})$ peak 
conditions: The upper is an eclogite-facies polymetamorphic complex (metasediments and upper Ordovician meta-intrusives, covered by thin Mesozoic carbonate metasediments), whereas the lower one consists of a blueschist-facies Permo-Carboniferous complex. The DMM is considered a slab of paleo-European continental crust, involved in Alpine-related E-dipping subduction, $\mathrm{W}$-verging continental collision and deep crust/mantle indentation [10,11], and is now stacked in the axial sector of the Western Alps and tectonically overlain by blueschist-facies and eclogite-facies meta-ophiolite units. Monte Bracco consists of phengite-bearing orthogneisses (Pietra di Luserna) and paragneisses, whose foliation is gently NW-WNW dipping (between $0^{\circ}$ and $20^{\circ}$ ), giving rise to an asymmetrical morphology, from the hilly relief on the eastern side, to the sub-vertical walls on the western side. Ortho- and paragneiss-hosted lenses and seams of quartzites (the alpine metamorphic product of the quartz-arenitic Permo-Triassic cover), are cropping out only towards the uppermost part of Monte Bracco (between 1100 and $1300 \mathrm{~m}$ a.s.l., an area of approximately $1.5 \mathrm{~km}^{2}$ ) and have been quarried as ornamental stones (Bargiolina). The thickness of the quartzite benches is between 2 and $10 \mathrm{~m}$, in sub-parallel lenses, from the lower to the upper: Banco Barmalunga (up to $10 \mathrm{~m}$ ), Banco Combale Rinaudo (7 m), Banco Savoia $(9 \mathrm{~m})$, Banco Tre Fontane $(2-2.5 \mathrm{~m})$ and Banco Quarzite di Tetto $(6-10 \mathrm{~m})$ [12]. The five quartzite lenses are interpreted as the product of isoclinal polyphasic folding and tectonic detachments [13]. The regional foliation is sometimes disturbed by low-angle brittle-ductile tectonic discontinuities and hydrothermal veins (quartz and tourmaline). The host gneisses are locally strongly altered to clay, especially close to the Banco Tre Fontane. Due to the abundance and good quality of kaolin, extensive extraction occurred in the past (up to $50 \mathrm{kt} / \mathrm{y}$ till 1997).

\section{Exploitation Setting}

From the XVI century the Bargiolina was quarried in a limited and discontinuous way, but a significant increase in its exploitation occurred from the 1794 thanks to the Trappist monks, who became suppliers of quartzite for many churches built at that time. If at the beginning of the XIX century the quartzite quarries on Monte Bracco were almost 40 in number, at the end of the XX century beginning of the XXI century only two companies from Barge municipality were exploiting the Bargiolina: Cave Gontero s.n.c. in Pian Lavarino and A.T.I. Tinarelli S.p.A. in the Pian Martino locality [12]. The quarry La Quarzite di Sanfront in the Sanfront municipality was stopped in the 80s of the XX century, due to the Banco Tre Fontane bench exhaustion. The quarrying method was based on explosives (detonating cord and gunpowder) or mechanical hammer (Figure 3). The yield rate of the quartzite was about $20 \%$, thus $80 \%$ of the exploited material represented waste rocks dumped on the slopes of Monte Bracco. Poor exploitation planning in the XX century, which involved the best portions of the rock body, caused the presence of partly exploited quarry benches, characterized by a yield rate (net production) of about $4 \%-8 \%$. The good material coming from the quarries was then processed to obtain stone for mosaic (nearly $50 \%)$, squared slabs $(8 \%)$, wall blocks $(15 \%)$ and waste from working activity (about $30 \%$ ). At the beginning of the XXI century, about $70 \%$ of the products were sold in European countries, and the major markets were France and Belgium. The low yield of the quartzite for slab production caused, and potentially can still cause, the production of a large quantity of waste, which must be well managed and potentially recovered (see Section 6). This factor, together with the strong competition by the widespread "golden quartzite" from Brazil (e.g., "Fantasy gold" quartzite, which shows similar aesthetical characteristics compared to Bargiolina (https://www.stonecontact.com/fantasy-gold-quartzite/s19476)) caused the progressive reduction of the quarrying activities to nearly zero production, which characterized the last decade. 

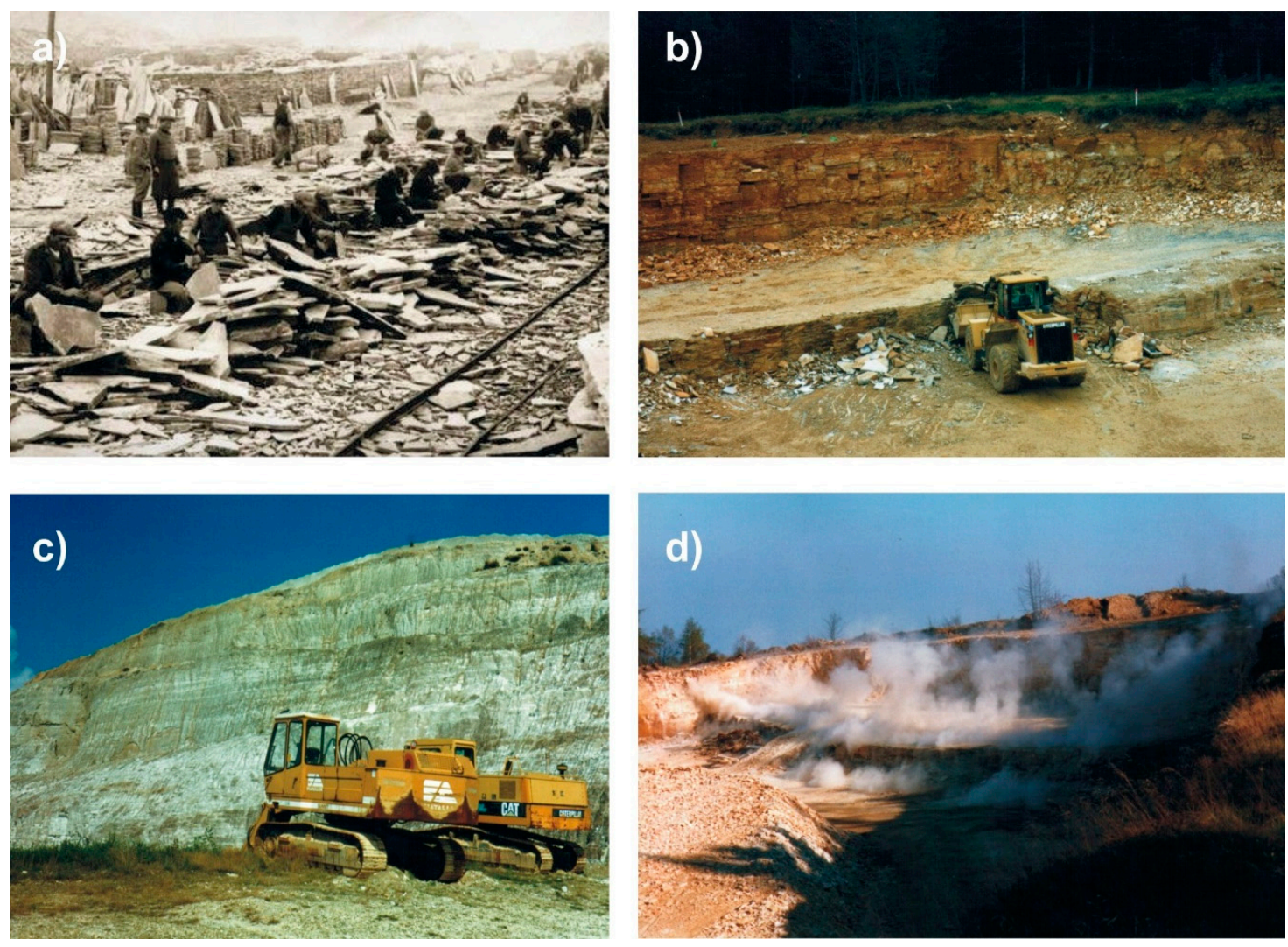

Figure 3. (a) Manual splitting of quartzite slabs at the end of the XIX century; (b) Pian Lavarino quarry front; (c) Tre Fontane quarry front; and (d) blasting at the Pian Lavarino quarry front.

\section{Commercial Varieties, Mineralogy, Petrography, Physical and Technical Properties}

There are four main commercial and chromatic varieties of Bargiolina: "golden" yellow (the most valuable, Figure 2a), pale yellow, olive green, grey and white (Marmorina, the most common). The main technical characteristic of the Bargiolina is the regular schistosity and the perfect fissility, due to the presence of thin, plane parallel white mica (phengite) layers. Because of this feature, it is possible to obtain very thin natural split slabs $(1-2 \mathrm{~cm})$. Under the optical microscope, the quartzite varieties show a quite homogeneous mineralogy and microstructure: A fine and homeoblastic grain size, a granular, lepidoblastic texture (Figure 4) with regularly spaced schistose domains (up to mylonitic); and small amounts of slightly altered K-feldspar porphyroclasts (orthoclase, 1-2 mm) give to the rock a micro-augen texture. The main rock-forming minerals (Table 1) are quartz (65-85 wt. \%, interpenetrating textures), white mica (phengite, up to $15 \mathrm{wt}$. \%), K-feldspar (orthoclase, 5-10 wt. \%, frequently altered to kaolinite) and traces of plagioclase (albite) and chlorite. Typical accessory minerals ( $\leq 1 \mathrm{wt.} \%$ ) are zircon, rutile, titanite, hematite, tourmaline (schörlite) and limonite. The different colors are linked to the different abundance and degree of oxidation of secondary minerals (goethite and/or limonite), presumably due to weathering and guided by fracture density and distribution. The kaolinitic host gneisses are rich in kaolin (up to $35 \mathrm{wt}$. \%) and quartz, with small amounts of phengite and chlorite; the whole-rock $\mathrm{Fe}_{2} \mathrm{O}_{3}$ content is generally $\leq 0.30 \mathrm{wt}$. \%. The chemical characteristics of quartzites show an $\mathrm{SiO}_{2}$ content ranging between 90-97 wt. \%, $\mathrm{Fe}_{2} \mathrm{O}_{3}$ concentrations between $0.17-0.48$ wt. \%, 0.3-0.13 wt. \% CaO, 0.05-0.35 wt. \% $\mathrm{MgO}, 2.84-8.17$ wt. \% $\mathrm{K}_{2} \mathrm{O}$ and $\mathrm{Na}_{2} \mathrm{O}$ around $0.30 \mathrm{wt}$. \%. Loss on ignition (LOI) is generally between 0.3 and $0.7 \mathrm{wt}$. \%. Usually the quartzite slabs are manually split, and the natural roughness of the surfaces is considered a quality for the application as paving, reaching the best slip resistance. The high values in compressive and flexural strength, as well as the low water absorption (Table 2) make these materials optimal for outdoor use, roofing and cladding (used, as above reported, also in important historical buildings). 

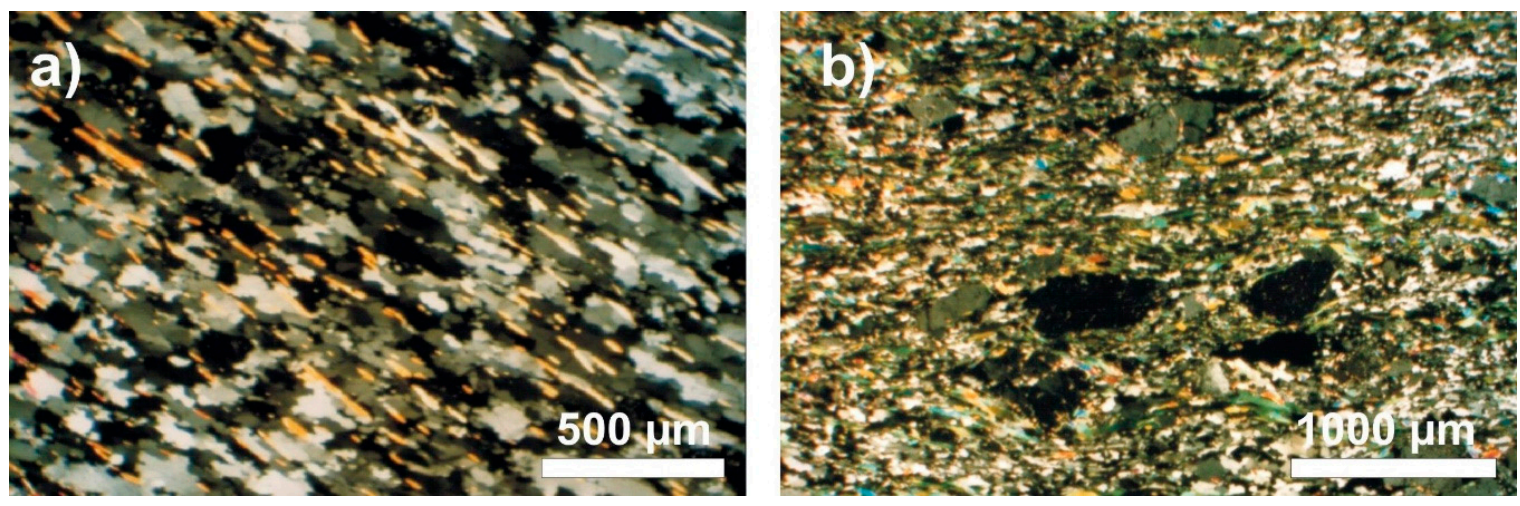

Figure 4. Thin section photomicrographs (cross polarized light) of (a) "golden" quartzite and (b) the Marmorina variety.

Table 1. Main rock-forming minerals (range) of the different quartzite varieties and kaolinitic gneisses. Abundances expressed as wt. \% from semi-quantitative XRD analysis.

\begin{tabular}{cccccc}
\hline & "Golden" Quartzite & Pale Yellow & Olive Green & Marmorina & Kaolinitic Gneiss \\
\hline Quartz & $90-95$ & $85-90$ & $85-90$ & $70-80$ & $50-70$ \\
Phengite & $2-6$ & $2-8$ & $5-10$ & $10-15$ & $5-15$ \\
K-feldspar & $1-2$ & $1-5$ & $2-5$ & $2-10$ & $<$ LOD \\
Plagioclase & $1-2$ & $1-2$ & $2-4$ & $2-4$ & $<$ LOD \\
Chlorite & LOD & LLOD & traces & traces & $3-8$ \\
Kaolin & LLOD & LLOD & traces & traces & $8-35$ \\
\hline
\end{tabular}

Table 2. Physical-technical characteristics of the Bargiolina ([5,6]; testing methods are reported in the two mentioned references).

\begin{tabular}{cccc}
\hline & On Average [5] & Marmorina [6] & “Golden" Quartzite [6] \\
\hline Bulk density $\left(\mathrm{kg} / \mathrm{m}^{3}\right)$ & 2579 & 2695 & 2695 \\
Water absorption coefficient (\%) & 0.21 & 0.28 & 0.30 \\
Flexural strength (MPa) & 40.5 & 55.5 & 42.3 \\
Impact strength (J) & n.a. & 7.4 & 7.4 \\
Impact strength (cm) & 102 & n.a. & n.a. \\
Knoop microhardness (MPa) & n.a. & 9010 & 9021 \\
Abrasion resistance (coefficient) & 0.67 & n.a. & n.a. \\
\hline
\end{tabular}

\section{Discussion and Perspectives: Sustainable Mining of the Mineral Resources of the Monte Bracco Area}

The extensive historical documentation, the several applications in prestigious buildings and the excellent technical properties make Bargiolina a material that deserves a Heritage Stone designation. The Monte Bracco area presents two other potential raw materials: The first consists of Bargiolina extractive waste (introduced in Section 4), and the second is represented by a wide area of kaolinitic gneisses. The quarry waste could become a resource: The quartz-rich composition and the abundance of kaolin in the altered host gneisses suggest interesting applications in the field of industrial minerals.

The morphology of Monte Bracco was perfect to hide the visual impacts connected to waste dumping activity, but not to avoid the problems connected to dump and slope stability. Only at the end of the XX century had the Local Authorities started to be interested in Bargiolina programmatic exploitation planning and in the waste rock management [14]. Currently, wide areas are occupied by extractive wastes, not anthropically nor naturally rehabilitated (Figure 5). Those extractive waste piles (irregular slabs, splints and chips) hide several quartzite body portions which could be potentially quarried. Thus, the exploitation of the waste might also be useful for future quartzite bench quarrying. Due to the high $\mathrm{SiO}_{2}$ (quartz) and low $\mathrm{Fe}_{2} \mathrm{O}_{3}$ content, the quartzite waste could 
be exploited as a secondary raw material and mineral dressed for ceramics, refractories, abrasives and glass manufacturing. The project planning for the quartzite waste exploitation is based on the physical-chemical characteristics of the rock and on the quantity of wastes, estimated to be 2,250,000 $\mathrm{m}^{3}$ (about $4120 \mathrm{kt}$ [15]). An interpolation of the data deduced from literature and information collected and processed during the present research (geological survey of quarry dumps) show that, after complete exploitation of the "virgin" quartzite benches, the rock wastes located in the Monte Bracco area should be evaluated as 4,940,000 $\mathrm{m}^{3}$ (ca. 11,660 kt; [15]). Physical and mineralogical characteristics of the material, waste volume and commercial product designation heavily influence the choice of handling equipment (power loaders, diggers, etc.) and of the mineral waste dressing processes.
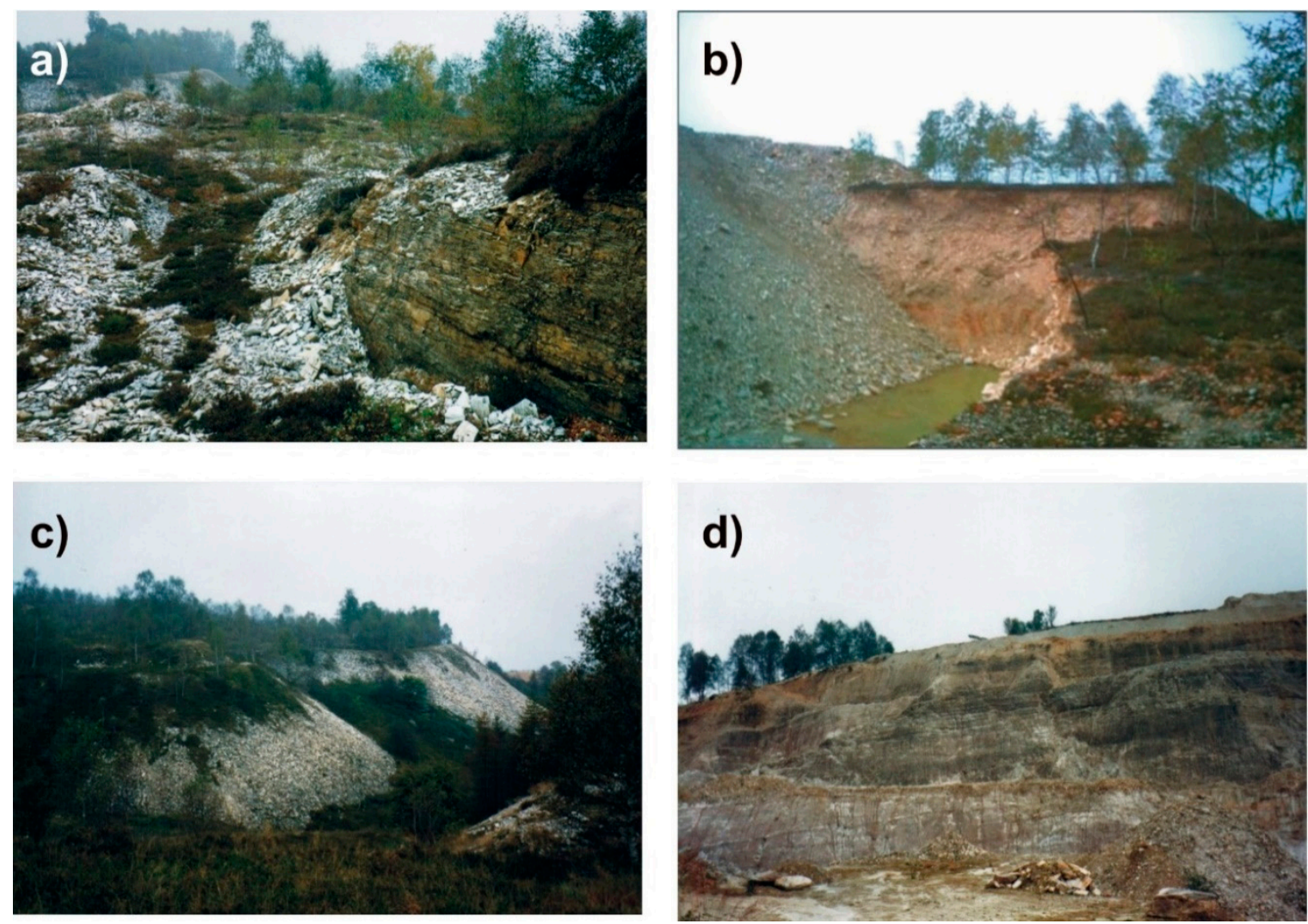

Figure 5. Present situation of quarry front and dumps. (a,b) Pian Lavarino waste-rock dumping area;

(c) Pian dell'Eremita quarry dump; and (d) Tre Fontane abandoned quarry front.

The exploitation of the kaolinitic gneisses in the Banco Tre Fontane area (Figure 1) should also be considered: Kaolin shows proper geochemical and mineralogical characteristics as an industrial mineral, which, however, should be extracted together with the quartzite (which lays on the kaolinitic gneisses bench). Preliminary data (XRD and XRF) on selected samples show a fair amount of kaolin and a very low $\mathrm{Fe}_{2} \mathrm{O}_{3}$ content, suggesting a hydrothermal origin (quartz veins, presence of tourmaline) and a good suitability for the ceramic industry. Finally, the chance to exploit the other kaolinitic gneisses on the slopes of Monte Bracco should be further evaluated: If the reuse of quartzite waste and kaolin-rich gneisses are feasible, a more targeted field geological survey, physical, chemical and mineralogical characterization of the potential deposit and total volume estimation (field and GIS investigations) are recommended [16]. In the perspective of sustainable mining, it is important to move towards an integrated exploitation of the Monte Bracco area, with contemporary exploiting of the quartzite bench (second class material—quarrying activity), the quartzite waste and the kaolinitic gneisses (first class materials—-mining activity for industrial minerals). 
Author Contributions: Conceptualization, A.C. and G.A.D.; methodology, A.C.; software, A.C.; validation, A.C. and G.A.D.; formal analysis, A.C.; investigation, A.C. and G.A.D.; resources, A.C. and G.A.D.; data curation, G.A.D. and C.A.; writing - original draft preparation, A.C. and G.A.D.; writing-review and editing, A.C.; visualization, A.C.; supervision, A.C. and G.A.D.; project administration, G.A.D.; funding acquisition, G.A.D.

Funding: This research received no external funding.

Conflicts of Interest: The authors declare no conflict of interest.

\section{References}

1. Di Francesco, G. La Pietra di Luserna a Barge; Chiaramonte Ed.: Collegno, TO, Italy, 1999; p. 135.

2. Sandrone, R.; Colombo, A.; Fiora, L.; Fornaro, R.; Lovera, E.; Tunesi, A.; Cavallo, A. Contemporary natural stones from the Italian western Alps (Piedmont and Aosta Valley Regions). Period. Mineral. 2004, 73, $211-226$.

3. Da Vinci, L. Foglio 1 del Manoscritto G; Biblioteca dell'Istituto di Francia a Parigi: Paris, France, 1511.

4. Snyder, R.L.; Bish, D.L. Quantitative Analysis. In Modern Powder Diffraction; Mineralogical Society of America Reviews in Mineralogy; Bish, D.L., Posts, J.E., Eds.; de Gruyter: Berlin, Germany, 1989; Volume 20, pp. 101-144.

5. AA.VV. Pietre del Piemonte. In Assessorato All'ambiente Cave e Torbiere Della Regione Piemonte; Regione Piemonte Ed.: Torino, Italy, 1973; p. 50.

6. AA.VV. Le Pietre Ornamentali del Piemonte; Regione Piemonte Ed.: Torino, Italy, 2000; p. 125.

7. Cadoppi, P.; Castelletto, M.; Sacchi, R.; Baggio, P.; Carraro, F.; Giraud, V. Note Illustrative Della Carta Geologica D'italia Alla Scala 1:50.000_Foglio 154, Susa; Servizio Geologico D’Italia: Roma, Italy, 2002; p. 127.

8. Dal Piaz, G.V.; Bistacchi, A.; Massironi, M. Geological outline of the Alps. Episodes 2003, 26, 175-180.

9. Compagnoni, R.; Rolfo, F.; Groppo, C.; Hirajima, T.; Turello, R. Geological map of the ultra-high pressure Brossasco-Isasca unit (Western Alps, Italy). J. Maps 2012, 8, 465-472. [CrossRef]

10. Balestro, G.; Festa, A.; Tartarotti, P. Tectonic significance of different block-in-matrix structures in exhumed convergent plate margins: Examples from oceanic and continental HP rocks in Inner Western Alps (northwest Italy). Int. Geol. Rev. 2015, 57, 581-605. [CrossRef]

11. Chopin, C.; Henry, C.; Michard, A. Geology and petrology of the coesite-bearing terrane, Dora Maira massif, Western Alps. Eur. J. Mineral. 1991, 3, 263-291. [CrossRef]

12. Dino, G.A.; Fornaro, M.; Martinetto, V.; Rodeghiero, F.; Sandrone, R. Le risorse estrattive del Monte Bracco: Valorizzazione mineraria e recupero ambientale. GEAM 2001, 104, 195-202.

13. Vialon, P. Etude géologique du Massif Cristallin Dora-Maira (Alpes Cottiennes internes-Italie). In Travaux du Laboratoire de Géologie de la Faculté des Sciences de Grenoble-Mémoires n 4; Université de Grenoble: Saint-Martin-d'Hères, France, 1966.

14. Bergamasco, L.; Fornaro, M.; Mangano, G.M. Applicazione di un Nuovo Sistema Informativo Territoriale per la Programmazione Delle Coltivazioni Minerarie ed il Recupero Ambientale; Il caso del Monte Bracco, PEI Ed.: Parma, Italy, 1998.

15. Dino, G.A.; Gioia, A.; Fornaro, M.; Bonetto, S. Monte Bracco quartzite dumps: Chance of recovery as second raw material for glass and ceramic industries. In Proceedings of the First International Conference on the Geology of Tethys, Cairo, Egypt, 12-14 November 2005; El Sayed, A., Youssef, A., Eds.; Tethys Geological Society (Egypt), Cairo University Press: Cairo, Egypt, 2005.

16. Dino, G.A.; Rossetti, P.; Perotti, P.; Alberto, W.; Sarkka, H.; Coulon, F.; Wagland, S.; Griffiths, Z.; Rodeghiero, F. Landfill mining from extractive waste facilities: The importance of a correct site characterization and evaluation of the potentialities. A case study from Italy. Resour. Policy 2018, 59, 50-61. [CrossRef]

(C) 2019 by the authors. Licensee MDPI, Basel, Switzerland. This article is an open access article distributed under the terms and conditions of the Creative Commons Attribution (CC BY) license (http://creativecommons.org/licenses/by/4.0/). 